Open Access

\title{
Status analysis and control measures of the debt risk in Chinese local government: based on the study of the relationship between "power, responsibility, and interests"
}

Xiaolin Miao

\section{Correspondence:}

xImiao1983@qq.com

Centre for Study of Public Policy in Yunnan University of Finance and Economics, Longquan Road no. 237, Kunming, Yunnan 650221, China

\begin{abstract}
From the view of current conditions and developing trends of the debt scale in Chinese local government, the debt crisis will explode in the near future if it cannot be controlled in an effective way. According to the regional distribution in China, except for Beijing, Shanghai, Tianjin, and Hainan, the debt risk is mainly concentrated in the western region. In a further step, it can be seen that this risk of debt is resulted by the imbalanced relationship between "power, responsibility, and interests" which contains non-accordance of debt power (such as debt-financing power), confusion of debt responsibility (such as debt-management responsibility), and distortion of debt interests (such as private benefit and public interests). For this problem to be corrected, using the local government's debt for private interests should be prevented, realizing the local debt behavior takes to the "faithful" service for the public interests. To realize this purpose, it is important to monitor the relationship between "power, responsibility, and interests," which is the most important factor for setting up the debt risk control system of Chinese local governments. In particular, the control system should include the following aspects. First, it should find the right time to empower local government with debt power. Second, on the basis of both positive and negative sides, it should design a system to restrict the debt responsibility in local government, which is necessary to solve problems such as new debt, invalid debt, and overdue debt expansion. Third, it should propose the guidance mechanism to realize the convergence from the private benefit to the social interests on the local debt.
\end{abstract}

Keywords: Local government debt, Risk control, "Power, responsibility, and interests" relationship

\section{Background}

At the meeting of the Third Plenary Session of the Eighteenth Central Committee of $\mathrm{CPC}$, it was presented that "a management and risk pre-warning mechanism should be established to regulate the normative and reasonable debt in both of the central and local governments." Soon after, the Fourth Plenary Session highlighted that the borrowing behavior of local government should be standardized by law, ${ }^{1}$ which mainly

\section{Springer}

(c) 2016 Miao. Open Access This article is distributed under the terms of the Creative Commons Attribution 4.0 International License (http://creativecommons.org/licenses/by/4.0/), which permits unrestricted use, distribution, and reproduction in any medium, provided you give appropriate credit to the original author(s) and the source, provide a link to the Creative Commons license, and indicate if changes were made. 
plays a role of forming an institutional system which could be adjusted with the evolution of local debt in China. It is either the inevitable choice to control the current risk or the important goal to reform the financial system in the future of China. With regard to how to build this institution, it also needs to be explored whether it should be in theoretical research fields or in practical departments. The institution is considered a type of stipulation or constraint for responsibility, which aims at avoiding the abuse of power due to pursuing special interests. ${ }^{2}$ As far as the debts of local government are concerned, being far away from the responsibility constraint would expand the debt power step by step as the private benefit corrodes social interests. This will then lead to the debt enlarging blindly, followed by an eventual explosion of the debt crisis. Therefore, to control and manage the debt risk efficiently, it is necessary to consider the relationship of debt power, responsibility, and interests.

This research has two goals. On the one hand, it will evaluate and adjust the debt status of the Chinese local government. On the other hand, by exploring the internal mechanism which is generated by the local debt, it intends to propose the measurement of precaution against the risk. Referencing relevant articles, this paper tries to create a new framework for the relationship between the debt "power, responsibility, and interests" in order to analyze its risk. The research emphasizes revealing the reason, from the view of imbalance relation of "power, responsibility, and interests," why debt behavior brings about non-social interests. Based on this, the original reason and relevant influential factors about the generation of the debt risk will be discovered, and then the long-term predicament of how to control it will be resolved fundamentally.

\section{The evaluation on the debt scale and risk in Chinese local government}

By the end of 2010, the debt balance of all Chinese local government was 107,174.91 billion yuan; by the end of 2012, the balance had increased to $158,858.32$ billion yuan; by the end of June in 2013, it had been raised to $178,908.66$ billion yuan, which turned over 59.74 times compared to 2994.82 billion yuan in 1997. Moreover, the rate of growth in 1998 and 2008 had reached $48.20 \%$ and $61.92 \%$, respectively, as shown in Fig. $1 .^{3}$

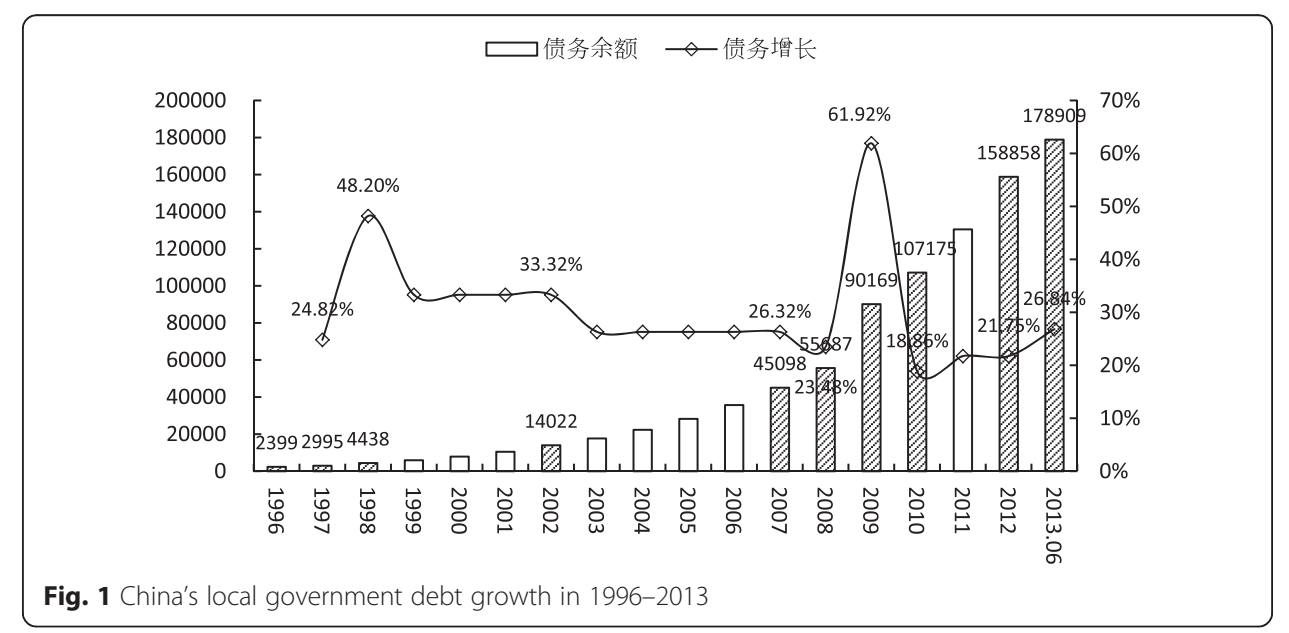


According to the Maastricht Treaty, the critical value of the debt is limited by the following two aspects. On the one hand, from the view of debt stock, the proportion of debt balance accounted for in GDP could not surpass $60 \%$. On the other hand, from the increments of debt, the proportion of it accounted for in GDP could not surpass $3 \%$. In the analysis of the local debt status in 2012, the balance proportion was $58.70 \%$ (which is equal to $158,858.30$ billion yuan/27,0591.98 ${ }^{4}$ billion yuan $\times 100 \%$ ), which was close to $60 \%$ (that means the referred critical value). At the same time, the increments proportion was $9.55 \%$ (which is equal to $25,841.705^{5}$ billion yuan/270,591.98 billion yuan $\times 100 \%$ ), which was much higher than $3 \%$ (the referred critical value). Thus, it can be seen that even though the debt balance of local government is being controlled, the new debt has exceeded the warning line. If the growth of the debt cannot be slowed down, the balance will soon surpass even the critical line. In fact, the risk has been so dangerous that the crisis may explode at any time.

In addition, from the debt distribution in various provinces (municipalities or autonomous regions), ${ }^{6}$ in 2012 there were many individual provinces over the critical line (which is $60 \%$ ) of the debt balance accounting for the local GDP, ${ }^{7}$ including Guizhou, Yunnan, Qinghai, Chongqing, Gansu, Shanghai, Shaanxi, Hainan, Beijing, Jilin, Tianjin, and Xinjiang. In June of next year, there are seven provinces with a higher proportion of new debt accounted for in local GDP, namely Guizhou, Gansu, Yunnan, Xinjiang, Qinghai, Sichuan, and Hubei, the values of which are all over $20 \%$. Even if Shanghai, Guangdong, and Shandong are taken to the lower rate of the debt balance in its GDP ${ }^{8}$ compared with the country's average level, their values have all exceeded the referred warning line (which is $3 \%$ ). Therefore, this may result in some provinces in the western region of China being the main concentration and presenting a higher debt risk besides Beijing, Tianjin, Shanghai, and Hainan, as shown in the Figs. 2 and 3.

The core issue of local government debt risk is the long-term and sustainable negative effect of fiscal deficit which manifests as local government debt. This therefore cannot form effective and sufficient fiscal income in the future, leading to the inability to maintain properly the performance of government function, ultimately making the fiscal operation unsustainable. The above shows that the rapid growth of local government debt

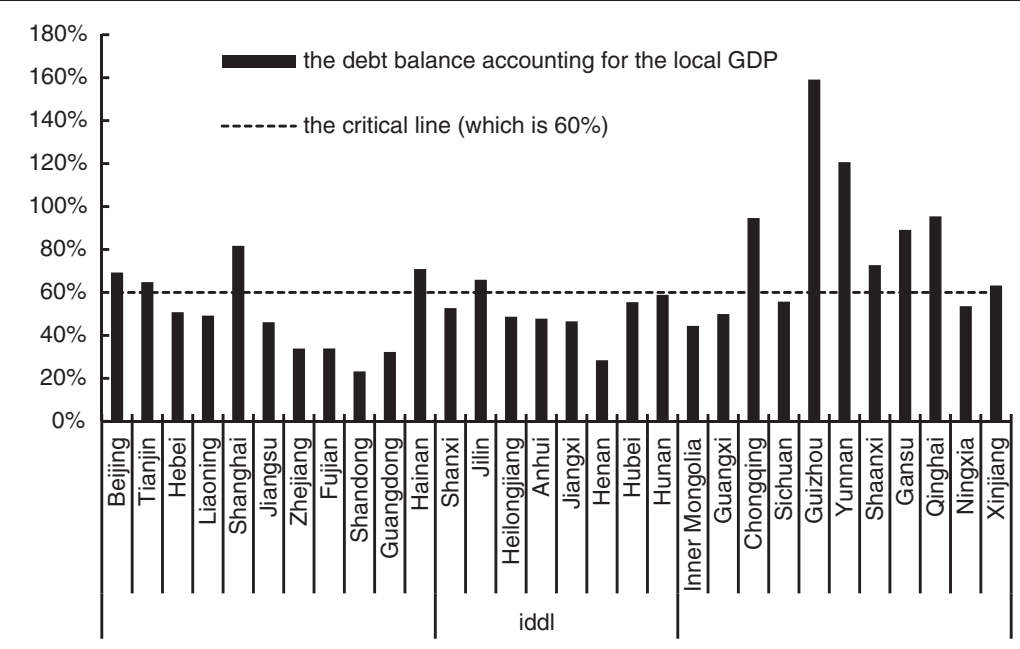

Fig. 2 Distribution for the proportion of local government debt balance to local GDP 


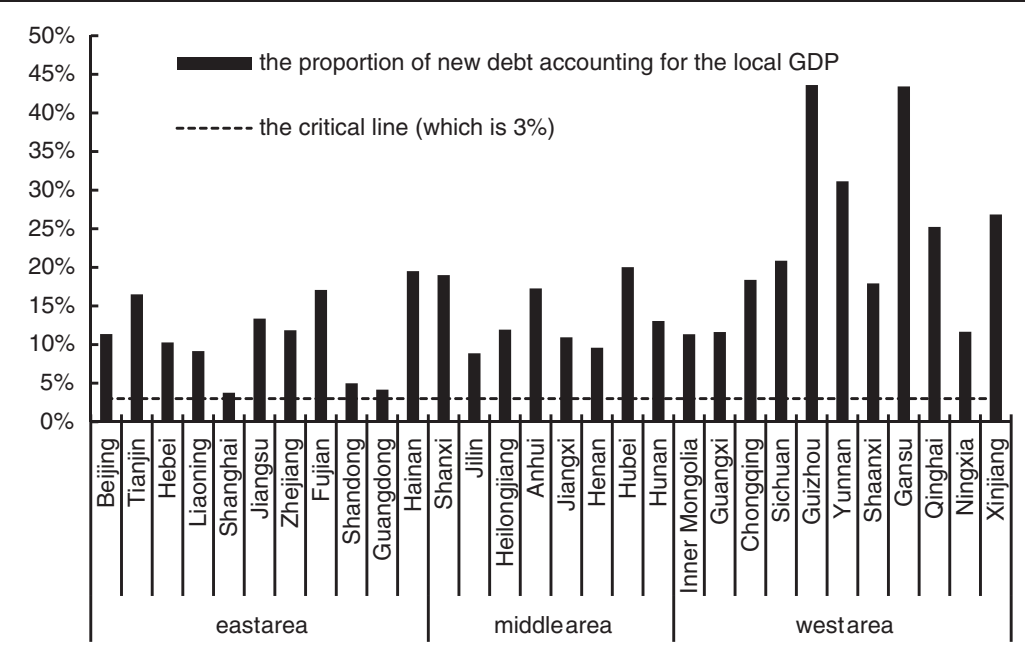

Fig. 3 Distribution for the proportion of local government new debt to local GDP

and debt burden ratio beyond the warning line in some areas both indicate the presence of local government debt risks. It is necessary to be aware that if the local government debt risk explodes, it will not affect just one city or fiscal province, but under the special system relationship in China, it will also trigger a systemic fiscal, financial, and economic crisis throughout the country. From the perspective of lending, the expansion of local government debt comes from the soft constraint relationship in credit between local government and financial institutions (Liu 2013; Xie and Bai 2013); the local government debt risk will inevitably spread to the financial system. In addition, the single state structure of China also determines that the central government will become the "final paymaster" of local fiscal burden (Huang and Xu 2011; Miao and Fu 2015); the debt risk of local government will eventually evolve into the central fiscal risks. The study of Fu et al. (2013) also elaborated that local government debt risk in China will possibly trigger an economic crisis. Therefore, strengthening the prevention of local government debt risk is not only the key to running local fiscal sustainability, but also the important premise to ensure the systemic safety of the economy. However, the most important key is finding the origin of local government debt risk.

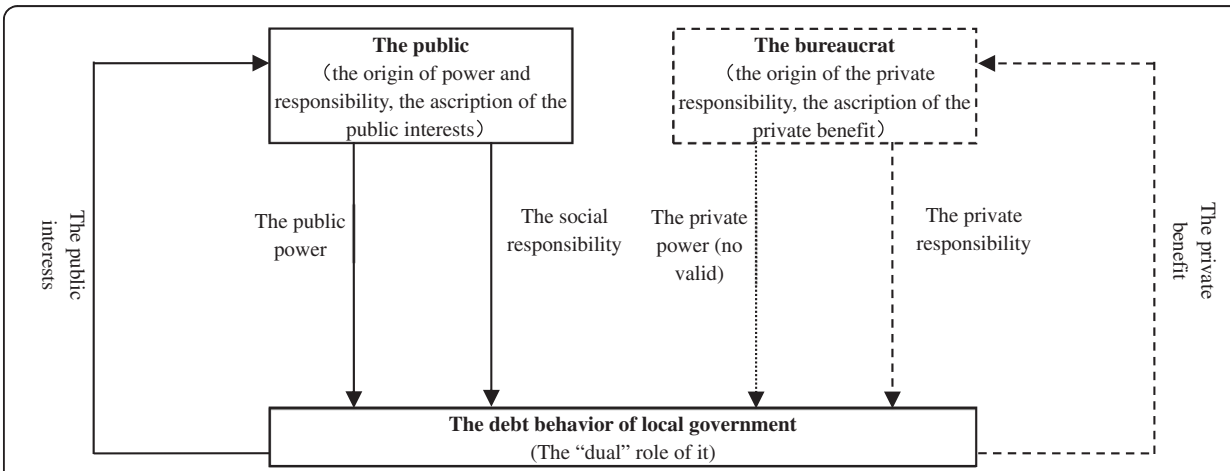

Fig. 4 The logic relationship between the debt "power, responsibility, and interests" of the local government. This figure describes the logic relationship between the debt "power, responsibility, and interests" of the local government, and should be placed before the title of 3.2 
Analysis on the debt risk of Chinese local government: based on the relationship between "power, responsibility, and interests"

Local government debt risk in China has been linked directly to the increasing abnormal behavior of local government debt. Most scholars have attributed the reason for the expansion of local government debt to the needs of pursuing economic development (Islam and Hasan, 2007; Lu and Research group of Jingan County branch of People's Bank of China 2011; Yang and Li 2013), fiscal resource and power mismatch (Mikesell 2002; Ming et al. 2011; Yu 2011), the removal of the debt management system (Levine 2011; Yang and Lu 2013), and other objective conditions. But all of these studies neglected the subjective behavior selection of local government, especially in the constraint condition that debt power broke away debt liability, in this situation, the infinite expansion of personal interests in local government will drive the expansion of local government debt. In the evolution of local government debt in China, incoordination in the relationship between "power, responsibility, and interests" which perform in the long term, greatly creates the conditions for the increase of local government debt.

\section{The reflection of the relations between "power, responsibility, and interests" on local} government debt

"Right" means a kind of interest which is protected by law. In the Modern Chinese Dictionary (2012), it is defined in the legal field that the power and interests are both being enjoyed by all citizens according to the law. Therefore, the right itself is combined with power and interests, which means the interests could be possessed only if the right is compared with the power, and the power could be realized only when the right is on the basis of the interests. Whether it is the power or the rights, they both aim at realizing the interests (Qi 2001). However, in the public field, the provision of power is for achieving public interests. Once this public power separates from, goes beyond, or goes against the right, non-public interests will inevitably be generated. On this condition, there is an important logical explanation: although public right is the common power of citizens and aims at realizing public interests, it is usually held and exercised by government officers. However, as the officer is also a person, the officer is also regarded as the main body of private interests. So both private interests and public interests co-exist, which may result in public power itself being generated from society in order to seek personal gain in order to rise above the society in return. Generally speaking, the right of society contains power and interests, and meanwhile it can be divided into public right and private right. The former is the unification of public power and public interests and the latter is the unification of private power and private interests. According to the hypothesis of economists, a person's for private interests tends to be endless. Under the limited condition of private power, the realization of it can only depend on public power, which will bring about a decrease in public interests or an expansion of public power.

"Responsibility" is an obligation or an assignment for maintaining the common interests. However, in the field of administration it is regarded as the commitment of punishment or blame to its own behavior. In the Modern Chinese Dictionary, there are three definitions for responsibility. First, it can make someone have an ability to take on some duty or obligation; second, it means doing something within one's duties; third, it points out that 
someone cannot do something well and therefore has to take all the blame. It can be illustrated that responsibility should be separated into both positive and negative sides. Positive responsibility plays a role in how things should be done; on the contrary, negative responsibility displays an obligate rule of how to be punished if a person does not take care of the positive side (Ma and Guo 2010). As above, responsibility can also be distinguished into private responsibility and public responsibility. The former mainly represents a kind of moral obligation which belongs to voluntary responsibility. The latter is associated with the endowment of public power, which aims at maintaining social public interests (Qi and Li 2006) and, therefore, it can be regarded as compulsory responsibility.

In general, the relationship of "power, responsibility, and interests" mostly includes the integration or the asymmetry of right and responsibility. The integrated relation mainly means the right and the responsibility need to adapt to each other, otherwise the unintegrated relation that leads to bureaucratic irresponsible behavior will. The integration of right and responsibility is therefore the basis to protect public interests from erosion (Qi 1988; Wang 2000). In other words, once endowed with public power, these public departments have to implement their responsibility for the realization of public interests. Therefore, it is proved that public interests have become the important bridge to connect public power with public responsibility. Meanwhile, public responsibility also has another function: to protect public interests from infringement of public power or to prevent abusing public power to seek private interests. These explanations amply demonstrate that public power and public responsibility should be unified in public interests. The asymmetric relation figures out that power is divorced from responsibility. If this asymmetry becomes much more serious, it will be harmful to public interests, which will cause the chain of power and responsibility to become much more fragile (Wei and Chen 2005; Guo 2009). The relationship between "power, responsibility, and interests" proclaims that the unification of public power and public responsibility is the key influence to maintain public interests, or else it will be damaged by the erosion of private interests.

The debt of local government belongs to the behavior of public policy so that relevant power, responsibility, and interests exist. They play different roles in debt. The first aspect is about the debt power of local government. The optical debt has its reasonability and object necessity, which could improve the local economy and bring about more efficiency, which means it benefits the social development. Therefore, the public would be willing to endow the power of debt financing and debt management to the local government. In most foreign countries, local governments have the power to issue bonds, including whether to borrow the debt, how much debt would be raised, who would become the creditor and the way of debt financing, etc. In 2014, the government issued a new "Budget Law" which brings a due power of debt financing to the local government. While it is clear that debt power is produced by the motivation of public and collective interests, it is not the private power of someone but the public power essentially. The second aspect is about the debt interests of local government. Being in the category of public interests, it mainly intends to make use of the action of debt financing to increase the capital input of constructing the infrastructure and various public services, and then make contributions to promote the development and structure of the economy, improve the quality of life and wellbeing of the public, and reduce the social cost of the enterprise production. Since the local officer is the person holding 
the debt power, the local debt is not only for achieving the public interests, but also for pursuing the private benefit which displays political achievement and rent-seeking profits. From the respective research, the political achievement of profit mainly reflects a person's private goal to get a promotion as soon as possible; the local officer takes an action to replace "expenditure efficiency" with "debt burden" which would lead to "short-term and high-speed" economic growth. Yaling Tan, the director of the Institute of Chinese Foreign Exchange Research, says that "the local government makes use of investment to help realize someone's achievement rather than improve the local economy." ${ }^{\prime 9}$ Rent-seeking profit means some other relevant beneficial subject has to bribe the officers for pursuing some debt power which transfers or detracts from the local government and then achieve the private benefit for himself. For example, some credit preference banks use bribery with the power holders to benefit from a kind of loan with "low risk, stable income" from the local government. What's more, some programmers will distribute the dividends to some power leaders in order to obtain the public welfare program contracts. It is obvious that the attraction of private benefit will push public power about the local government debt separating, surpassing, or even deviating from public interests so that the original public interests will be damaged. The third aspect is about the debt responsibility of local government. In fact, this role is to restrict a person to use this public power for personal profit. The social public should be the carriers endowed with the responsibility to the local government, because they are the givers of public power of local debt financing. On the positive side, the content of responsibility involves stipulating the issue of how to realize the social interests by the local debt, such as confirming the debt scale and structure, managing the debt use and efficiency, redemption of the debt and controlling the risk, and so on. In contrast, on the negative side, the responsibility mainly means the local government would be punished if it goes against the social interests from the debt. In practice, this punishment mostly aims at abusing the debt's public power to seek personal profit, therefore, this kind of responsibility mainly restricts the local leader's behavior. For example, this punishment includes accountability and administrative penalties to the local officers who take debt financing blindly for the pursuit of short-term economic growth or who accept bribes and distributed profit from some other related stakeholders. In fact, the responsibility restriction of local debt behavior is security to preserve the public interests.

From the above exposition, the debt power of local government is endowed by the social public. The purpose of this is for the realization of public interests which are brought from the local debt. To safeguard these interests, the public is of the view that requires the local government to carry out its positive responsibility of relevant debt management and the negative content regarding the punishment of not undertaking the positive responsibility. After that, the contract between the local government and the public is formed, which refers to the relationship between the debt "power, responsibility, and interests." However, this contract is unstable because the local government plays a "dual" role, which represents both the public's benefits and the bureaucrats' profits. Except for the aim of public interests, there is also private benefit to be realized by the local government's debt. Meanwhile, compared to public interests, it is easier for private benefit to play the leading role. ${ }^{10}$ As far as private benefit is concerned, it is hidden in the relationship contract between the debt "power, responsibility, and interests" of the local government and the bureaucrats. In this condition, the private power of 
local debt is not valid but the private responsibility needs to support the service for private interests, which means the "instruction" should be issued that public power will be used by the officer in local government. Once the local government begins to utilize the public power of the debt to serve for personal profit, it is appropriate that the social responsibility of the debt should play a part in the constraint and punishment. If it does not play a role in that, public power would contribute to the private benefit without limit, which will cause great damage to public interests. Finally, it would become inevitable that the debt will expand in scale and be used indiscriminately. On the other hand, if the public power of the debt could contribute to the public interests "constantly," the private benefit hardly impacts the use of the debt. Thus it shows that the social responsibility of the local debt has an important effect on the coordination between public power, public interests, and private interests, and it could then make efforts to regulate the behavior of the local debt and control the risk.

\section{The imbalance reflection of the debt "power, responsibility, and interests" in Chinese local government}

The above research about the relationship between the local debt "power, responsibility, and interests" shows that both the debt scale expansion and the risk formation are essentially a result of the debt responsibility being unable to "control" the corrosion from the government officer. From the current situation of the local debt, it could come down to the following three reasons:

(i) When the new "Budget Law" of 2014 had not been issued, the local government in China was not endowed with debt power in principle. But in fact it carried out some debt financing behavior according to some reasonable, and even unreasonable, terms. This kind of absence of power, which is in name only, makes an excuse for itself from the true debt responsibility and supports an opportunity to satisfy private interests.

From the development history of our local debt, there were only a few reasons for the local government to be allowed to borrow money by the central government. In 1950, the People's Government in Northeast of China issued "the government bonds for the production and construction of northeast regions"; in 1958, the government bonds of "constructing the local economy" were issued in various areas; from 1998, some national bonds started to lend to local governments; since 2009, central finance has been commissioning local governments to issue bonds. Except for these actions, other local debt financing is all beyond legal rights. They could be restrained by some relative policies, for example as in 1985 when the State Council regulated that the local government was not being allowed to issue the bond by itself; the Budget Law of 1994 pointed out clearly that the local government had no rights to issue its own bonds; the amendment of Budget Law in 2012 finally confirmed that local government had not been allowed to issue its own bonds. These rules illustrated completely that if there are no debt rights to be endowed to the local government, it is not allowed to produce the debt, and there is also no reason for the local government to undertake any social responsibility of the debt for achieving the social interests. However, the fact is quite the opposite. The local government deliberately bypasses the action of issuing bonds which is prohibited by the law. Instead, there are a large number of debts being borrowed by way of the investment and financing platforms. Taking an example from 2012, deducting 233 billion yuan of legitimate 
municipal bonds which were agent issued by the Ministry of Finance, the new local debt accounts for over $99 \%,{ }^{11}$ which is produced under the illegitimate condition of not endowing the true power of debt financing. That means almost all local governments are beyond their legal power. It seems that the debt behavior of local government has been the established fact, which is neither approved by the legal power nor restrained by the relevant departments. From the above analysis, it could be summarized that this kind of debt behavior is hard to supervise and restrain (and therefore hard to regulate its responsibility) because of the lack of political power. This status then easily brings about the erosion from the private benefit for the power holders to the public interests, therefore, the debt scale is bound to make grow.

(ii) The lack of debt power in local government results in there being no reason to regulate and control debt financing. In fact, in China, effective methods for managing local debt are unavailable and this will turn this essential "unregulated" behavior to "doing whatever it wants to." After that, the goal of social interests is harder to achieve. In fact, the debt responsibility of local government is the foundation to catch social interests; that is to say, if there is no responsibility to be undertaken, it is out of the question to realize social interests. However, from the practical status of Chinese local government debt, since there is no debt power to be given, the local government has no incentive to allocate the respective responsibility, which is in agreement with the principal of integration of power and responsibility. Furthermore, it is even more unlikely to make the main bodies of holding power regulate the local government undertaking the debt responsibility. In fact, there have been only a few relevant management rules or methods about local debt to be approved by the central government, such as "the People's Republic of China regulation on the public bonds to construct the local economy" (which was in 1958) and "the management method of the national debt transmitting to load the local government" (which was in 1998). Apart from those issues, the Chinese central government has not announced any other policies to manage local debt, which involves the local government not being responsible for anticipating the decision, taking management, and later taking payment in the process of borrowing, using, and paying the debts. Needless to say, the punishment for the negative debt responsibility represented by local leaders is not to implement the debt responsibility actively. The blank of the local debt responsibility will lead to the private benefit continuous to erode into the social interests, which will improve the scale expansion of the unreasonable local debt. Of course, it is difficult to complete the goal of social interests.

(iii) Since the "Fiscal Responsibility System" and "Tax Sharing System" were carried out in 1978, most local governments have obtained their respective political interests from economic growth. Because of this, they have the urge to make use of debts to promote economic development. Based on this, they were seeking the "reasons" which are advantages for economic progress to expand the debt scale. However, these "reasons" and the following motivation always have the private benefit guidance. Different profit guidance will contain different characteristics of local debt financing. If approving debt financing on the basis of private benefit, local government could be in accordance with the "reason" of developing the social economy in order to borrow a large number of debts, and then leaders would gain the political achievement and rent-seeking profits from it. On the contrary, if approving debt financing on the basis of social interests, local government has to control the debt scale by considering the various aspects of the accompanied risk, 
the debt sustainability, and the efficiency of utilizing debts. From the practical situation in China, without comparing the debt power, local debt financing is not restricted by the responsibility, which makes it difficult to guarantee the realization of public interests and has been replaced by private benefit in large degrees. According to the development history of local debt, before 1978 the local government did not have any activities to need debt financing' the most important reason is that, under the traditional fiscal system of state-monopolized revenue and expenditure, it is almost impossible to realize political interests by debt financing. On the other hand, this behavior would create a burden on its own. After the reform and opening-up policy, the fiscal system moved into the stages of "Fiscal Responsibility System" and "Tax Sharing System," which means the better development the more interests for the local government. In addition, with the two international economic crises, expansionary fiscal policy had been put into effect, which created the opportunity for debt financing and made further tide of capital raising for the local government. From the trend, it can be analyzed that, under the current fiscal system, much of the rapid expansion of local debt depended on the inadequate views of political achievement; that is to say the corruption of private interests under unrestricted conditions.

Preventing and controlling the debt risk of local government: realization of the relationship between the "power, responsibility, and interests"

Based on the above research, if want to prevent and control the debt risk of Chinese local government, an important step is to realize the relationship between the local debt power, responsibility, and interests. The core method is to make an effort to prevent social interests from the corruption of private benefit through debt responsibility. In particular, there are three aspects, which endow the debt power to the local government in real time, assuring the debt responsibility of the local government reasonably, truly transforming the debt interests of the local government.

\section{Timing selection to endow the debt power of the local government}

From worldwide experience, local government in most countries owns the debt financing power, which is ruled clearly by the law and restrained by the relevant provisions. As far as China is concerned, it is because the debt power has not been given to local government and debt responsibility cannot therefore be implemented and social interests will be corrupted seriously by private benefits. So, why doesn't the State have legal regulations to allow local government to issue bonds? In fact, it is just for selecting a suitable time which means a period with the mature system of the local debt management. There is no harm in making an assumption that local government has been allowed to issue bonds. Under this assumption, local government truly has the power to finance debt and could issue bonds in the public way. However, it also has the respective obligation of being responsible for the debt, or it would be punished by the superior government if it defaults its responsibility. This unification of debt power and responsibility seems to control the debt risk effectively, but the necessary condition is the kind of responsibility for the debt management that should be implemented by local government. In the long term, the management system of the local debt stays in a "vacuum" situation all the time. It has been presented that neither the management methods nor the scale and structure of the local debt should not be held and controlled by the central and local governments, needless to say the management responsibility. Therefore, if the local government is 
endowed the financing power under immature conditions, it only results in raising the debt risk.

Of course, without the endowment of debt power, there would be no exploration to regulate the debt responsibility of local government. To resolve this contradiction, a systematic and perfect responsibility policy needs to be set up and this should be carried out in some pilot regions to manage the local government debt, and then be extended gradually to other areas. That is to say, accompanied with the debt responsibility being attached and improved nationwide, the power of that could be opened up step by step. In fact, from the view of issuing "the method of choosing some pilot regions to issue its own bonds," selecting Shanghai city, Zhejiang province, Guangdong province, Shenzhen city, Jiangsu province, and Shandong province as the pilot regions to issue the local bonds and action being taken by the Ministry of Finance to bring local government debt into the budget and so on, they all reflect that the responsibility policy to manage local debt has been building throughout the country. The new "Budget Law" of 2014 has stipulated that the debt power of local government should be locally opened up. As this policy is being developed, the local debt power will be endowed gradually in various regions.

The mechanism design of confirming the debt responsibility of the local government The confirmation of the debt responsibility of local government is for regulating local government behavior about debt financing, using, and payment, which involve the regulation of both positive and negative responsibilities. This is either to supply the strength for the power endowment or to offer the essential guarantee for social interests.

(i) Positive responsibility: it is to roll out the supervision mechanism for local debt. Setting up the mechanism is for restricting the relevant responsibility according to the different links of debt financing. Based on this, the normative debt management of local government should be succeeded. In other words, this regulation of the debt responsibility has a positive sense. Meanwhile, it mainly runs through three managing steps of debt financing, using, and payment, and the important purpose is to control the debt expansion about the new debt, valid debt, and overdue debt. First, aiming at the new debt expansion, a mechanism to supervise debt financing should be set up. The expansion of the new debt is regarded as the first part of the debt risk, which is mainly produced by the irrational behavior of local government borrowing debts from financial institutions. According to this behavior, a system to restrict debt responsibility should be designed, and this should mainly include three supervisors such as the social public, the superior government, and the financing platform. With this, at the beginning, a decision-making mechanism to adjust the demand of the debt expenditure should be available. It is executed by the social public (who is one of the supervisors) that they should make their decisions about whether the debt financing of local government can be acted. Meanwhile, being a delegate of the social interests, the public have to evaluate the purpose of local government to create the debt and the sequence of programs which are involved in some budget plan of debt repayment. Furthermore, based on the demand preference of the public services, a plan to design the debt scale and structure would be 
formed. This mechanism mainly involves three parts: the approval mechanism about departmental revenue and expenditure, the expression of interest mechanism about the expenditure preference, and the evaluation mechanism about the program budget. Second, a decision-making mechanism about the ability of local government to carry the debt should be offered. Being another supervisor, the superior government, from the consideration of the debt-carrying ability, could decide the debt scale and structure for the lower levels, which is in order to ensure the optimum improvement of the debt for social economic development. This mechanism is mainly contributed by the information collection system, the debt calculation system, and the leading system for decision. Lastly, it presents the decisionmaking mechanism for local debt financing. From the debt paying ability, the financing platform (being the third supervising body) should be given a right to adjust the scale and structure of local debt financing, which intend to restrain local government to repay the debt by itself. It might take actions to set up an independent financing platform from the government, a debt decision-making system on this platform, and a financing mechanism. This kind of responsibility restriction mechanism not only plays a role to satisfy the citizens' willingness to contribute to public services with the debt expenditure, but ensures the debt expenditure could be an advantage for the macroeconomic operation, and even have the possibility of repaying debts on time.

Regarding the valid debt, a mechanism to supervise debt use should be set up. In particular, the debt risk also displays whether the local government use it ineffectively or even excessively. This results in local government blindly making use of the debt captures to pursue short-term economic growth, which is an irrational behavior. According to this problem, a system to restrict its responsibility should be put in place. In this system, the public and the superior government are the main restricting bodies who both stand for public interests and constrained power. Among this, both of the mechanisms to restrict debt use and the mechanism to supervise debt efficiency are to be offered. From the former side, it is pointed out that the public should take action to the internal restriction which has an effect on the debt before it is used by local government. The goal is to require local government to make a reasonable budget before debt financing and execute it strictly, in order to make immune the adverse selection of local government during the process of the debt use. It involves designing a rigorous budget plan of the debt expenditure, establishing a rigorous accounting system to examine the debt, improving the bidding mechanism of the government procurement, and strengthening the treasury concentrated payment system. From the latter side, it mainly considers the superior government as the other subject who implements the external restriction responsibility. A mechanism should be built to evaluate the debt efficiency, which plays a role to check the local government behavior of debt use since it has taken place. The purpose is to supervise the local government modifying and improving its behavior about debt expenditure. It is contributed from establishing some examined mechanisms aimed at the debt management, the planned outcome, and the expenditure efficiency. From the above statements, it can be seen that this kind of responsibility restriction mechanism pursues achievement of the efficiency improvement of debt use through the main subjects of the public and the superior government. 
However, the restriction from the public emphasizes the action beforehand; on the contrary, the superior government holds this restriction to subsequent conduct. Lastly, facing the expansion of the overdue debt, a mechanism to supervise the repayment should be set up. The debt risk will also be expanded if the local government cannot implement the repayment responsibility, even though the above problems about the new debt and the valid debt have been solved. As for the debt repayment being delayed or defaulted, it should be with the aid of the superior government, the financing platform, and the social public to establish a system to restrict the responsibility of the local government. This mechanism mainly involves three aspects. First, it is the mechanism to evaluate the implementation of the debt responsibility according to the repayment plan: the superior government should monitor and examine the main appointed subject with the repayment responsibility and the progress towards the repayment plan. Confirming who should repay the debt should be the core task, which refers to establishing the approval and evaluation system for the repayment plan and the implementation of the debt responsibility. Different conclusions could be made following the different degrees of repayment behavior. If there are any conditions that do not mesh with the plan, this mechanism should be used not only for supervision but also for modification. Next, it is the mechanism to evaluate the credit rating of the local government from the default of debt repayment. According to the actual repayment conditions, this evaluation mechanism should be built by the financing platform. This result will be important information to be offered to the financing platform, which use it to adjust the further financing ability of the local government. The inclusions are the credit rating evaluation mechanism of the local government being contributed by the financing platform, which depends on the evaluating standard according to the default extent, as well as the financing influence mechanism being associated with the credit rating directly. Third, it is the mechanism to reserve some currency to deal with the repayment. The contribution and improvement would be under the personal supervision of the social public, which contributes to reduce the default risk to impact the fiscal normal operation. It mainly contains the decision of the capital source, the management methods, the used conditions, and so on. This kind of mechanism to restrict the responsibility both urge the local government to repay the debt on time and support the financial security to repay the local debt.

(ii) Negative responsibility: a mechanism to punish some misconducts about local debt behavior should be set up. On the positive side, the restrictions focus on what the local government should do during these three links of borrowing, using, and repaying debts. However, local government is not a government with responsibility under ideal conditions. It can bypass the above supervision mechanism successfully, and even more through some other ways to expand the debt power which intends to pursue the private benefit. Therefore, it is necessary to construct the restriction mechanism on the negative significance. That means local government would be punished if it is not in accordance with the requirement to borrow, use, and repay the debt. The ultimate goal is to guarantee the control of the negative restriction to the positive one. It is worth noting that some violations of the local debt financing are mainly results of the expansion of private benefits compared to social interests. That is to say, this punishment is aimed at the 
government bureaucrat instead of the whole social group. As far as the bureaucrat is concerned, private benefit, which is closely related to local debt, mainly involves the achievement profit and rent-seeking benefit. Meanwhile, the punishment also plays a role in preventing social interests from the erosion of these two personal behaviors. The main process is that the superior government, the public, and the platform evaluate and examine debt behavior from different views. After that, the comprehensive report should be completed and then submitted to both the superior organization and personnel departments and the superior discipline inspection and supervision departments. After approval, it could become the basis on which to constrain the debt behavior of local government, especially including the two important aspects about the evaluation and identification. On the one hand, the mechanism plays a role in evaluating debt behavior. It is carried out by three main bodies: the superior government, the social public, and the financing platform. Among this, the superior government mainly holds the decision mechanism of debt-carrying ability about the local government, the supervision mechanism of debt using efficiency, and the evaluation mechanism of implementing the debt repayment plan; the social public taking this evaluation mainly relies on the decision mechanism of the demand preference about the debt expenditure, the restriction mechanism of the debt use, and the reserve mechanism of the debt repayment; the financing platform taking the evaluation focus on the decision mechanism of the debt financing about the local government and the credit rating evaluation mechanism of the debt repayment default. Whatever anyone makes of any mechanism, the evaluated objects are all behaviors shown by local government, including the submission and implementation.

On the other hand, the mechanism also identifies the debt behavior of local government. It is carried out in the same main bodies as listed above: the superior government, the social public, and the financing platform. They need to submit the evaluation report separately to both the superior organization and personnel departments and the superior discipline inspection and supervision departments. Afterwards, on the basis of this report, they would identify local debt behavior and then carry out the relevant incentives or punishment policy. Generally speaking, the organization and personnel departments are mainly in charge of the achievement identification according to local debt behavior, and use it as the basis to promote, transfer, or remove some relative local leading cadres, which play a role to prevent the social interests from the erosion of the achievement interests of the local officers; the discipline inspection and supervision departments are mainly responsible for the legal identification to debt behavior of local government, and on this basis, some relevant leading cadres can be investigated for the legal responsibility, which aims at preventing the social interests from the erosion of the rent-seeking benefit.

\section{The guide measure to transform the interest-orientation of the local debt}

Transforming the interest-orientation of the local debt, the core purpose is to realize the convergence from private benefit to social interests, which is regarded as an endogenous precondition to guide the local government to implement the debt 
responsibility consciously on the subjective sense. In any case, as long as the local government has the sense to reach the social interests, it is not impossible that the scale and risk of local debt could be controlled and treated effectively.

(i) The guide measure should emphasize the positive motivation of the private benefit. The keynote is to develop the government's officers to raise social responsibility consciousness in a subjective way and to make the private benefit close to the social interests continuously in a positive and conscious way. As far as debt management is concerned, it mainly requires the officers to transform the goal from the maximum private benefit to the maximum social interests regardless of the process of debt financing, using, and repaying. But if this transformation is to be completed from the positive side, the important measure is how to change the officers' interest idea from their thoughts. It might contains three steps: from the view of selection and appointment, on the basis of meeting the ability requirement for work, their political awareness should be examined more strictly; as for the civilization and cultivation, some good examples should be offered for influencing the officers' behavior so that they could keep the faith consciously; in the respect of assessment and incentive, their confidence and motivation should be enhanced to uphold the social interests.

(ii) The negative erosion of the private benefit to the social interests should be restrained. The important reason why private benefit is difficult to get close to social interests is that there are a great many different interests available for achieving the private demand, such as the "political achievement" profit, rent-seeking benefit, and others. However, the unlimited private demand would bring about the unrestricted expansion of these interests. If this action could be restricted effectively, the officers will not have any opportunity to reach the private interest. Under this condition, they have no choice to consider the social demands so that the convergence would be succeeded from the private benefit to the social interests. Of course, this measure in itself is considered by the thought of "constraint" so that it should be accompanied with a perfect action system of "constraint." As far as the "political achievement" profit and rent-seeking benefit are concerned, both are widely found to achieve the personal interests though producing debts. To resolve these problems, on the one side, it should aim at changing the "political achievement" idea completely, the particular methods of which include the long-term economic effect generated from the debt expenditure and the responsible risk produced later which are both regarded as the evaluating standards to examine the social interests. It also bought into the scope of the political achievement assessment; on the other hand, it should focus on rent-seeking during the debt process. As for this behavior, the punishment should be taken severely. With any lawbreaking activities referring to debts, the leader of local government should suffer from the harshest punishment; at the same time, other officers should be on the alert so that their perverse motives of seeking rent profit can be quashed.

(iii) This measure should eliminate the responsible transformation about the behavior to pursue private interests. The reason for not implementing the responsibility of debt management is that local officers have seen that the debt responsibility could be transferred in various methods, such as transforming into the superior 
government and the next government. Therefore, to actually realize the conscious implementation on local debt management responsibility, more efforts to eliminate the transferring anticipation are needed, which is in order to reach the private benefit and drive the independence of local government on the acceptance of the debt responsibility. In particular, the contents are as follows: for one thing, it should weaken the space transformation anticipation of the debt responsibility as for expecting the debt aid from the central government. For example, the central government should adopt some punishment measures which are used to dismiss and punish the local officers who have not undertaken the debt responsibility, but that is what they should be doing. After that, local government could also obtain help from the central government. However, it must pay a high price as the administrative penalty. For another, it should weaken the time transformation anticipation as well which transfers the debt responsibility into the next government. Try to clearly define the local government responsibility of the debt financing and using, to help hold it accountable. Meanwhile, this responsibility must be accompanied by the relevant officer at all times, whether he has been transferred or even promoted.

\section{Conclusions}

This paper tries to resolve the unbalanced relationship between the "power, responsibility, and interests" of local debt in China, which is on the view of the power endowment, the responsibility restriction, and the interest transformation. The goal is to afford some lessons to control the local debt risk in China. However, to operate the above mechanisms, it depends on the safeguard which is formed by the institution perfection and the policy adjustment in the macro field. In practical terms, the first one is to ensure the legal basis for the debt power and responsibility. The power is the operation start and the responsibility is the code of conduct. In case of missing the restriction to the power and responsibility, the debt will be expanded as it is much harder to shake off the erosion of private benefit. Thus, the legal norm must be established for carrying the power and responsibility of the local debt, which is really the way in favor of the functional running of the debt management mechanism. The second one is to change the idea of the local officers as for the achievement assessment. As far as debt management is concerned, to help change this idea, try to consider some indicators of the local debt cost with spillovers into the examination system, which involve the debt efficiency, the debt risk, and so on. The purpose is to make local government have the sense of the debt responsibility while developing the economy. The third one is to guarantee basic financing for improving local development. For some factors such as the political system the local government can hardly provide enough money, the financial gap will be more serious, and the demand to the debt will become more urgent as well. The more serious this gap, the easier it is to cover up the irrational and irregular behavior of debt financing. So try to establish and perfect the basic financing safeguard mechanism at all levels of government, to eliminate any possibility of the local debt financing blindly. The next one is to set up a budget system to manage the local debt. From the consideration, the governments at all levels should have more emphasis on how to build a budget system meeting the requirements of the modern budget system. One of the important reasons is that only by bringing the local debt into the budget management can the scale be controlled effectively and be managed regularly. In a 
further step, this will lead the continuous debt expansion and then make a threat to the financial, monetary, and economic security in the whole country. The last one is to enhance the information disclosure mechanism of the local debt. If there is a large amount of non-transparent information about local debt, it would bring about many of them being outside the statistics and kept in the invisible position. The more important is the behavior about the relevant debt power is difficult to supervise and control. As a result, it is necessary to establish a perfect mechanism to disclose the information of the local debt, which needs to improve the accounting system, strengthen the auditing mechanism, and regulate the system of statistical management and so on.

Fortunately, from the recent corresponding reform of the local government debt, the state is continuously changing the abnormal relationship between the "power, responsibility, and interests." The essential purposes are focusing on intensifying the social responsibility of the local government, realizing the private benefit of the local government on the debt converging to the social interests of that and guaranteeing the normal increase of the debt. From the developing progress: at the beginning of 2011, the central government tried to select some regions as pilots to put into force a policy allowing the local government to issue the debt by itself. In fact, this action expresses that the central government has been endowing the power of issuing debts to the local government in some areas, which intends to create a policy to be available widely for managing local government debt. It will lay the foundation for restraining the local government's behavior from the debt responsibility in the future. On 6 December 2013, "the notice on the improvement to examine the political achievement for the local party and government leading bodies and other leading cadres," ${ }^{, 12}$ which has been issued by the Organization Department of the Central Committee of the CPC, put forward clearly that "the government debt is regarded as an important index to examine the political achievement, ... what some problems such as 'the new leader ignoring the old debt' and 'taking up the offspring resource' are being the important reference to evaluate the leading bodies and cadres," meanwhile, "as for borrowing blindly to make a large of bad debts, this action must be on the record and then the officer must be given the punishment by the organization or on the party or policy discipline according to the circumstances, even referring to the departed leaders." This measure is actually of the view of the political achievement to enhance the sense of the local government to undertake the debt responsibility. On the one hand, the irrational political achievement concept should be corrected through examination; on the other hand, the power to borrow the debt blindly should be restricted by the responsibility life tenure. In 2014, the new "Budget Law" has been issued, which plays a role of the debt power of the local government being endowed properly so that it makes a foundation for confirming the debt management responsibility of the local government.

\section{Endnotes}

${ }^{1}$ The data come from the National Finance of Sina website, "Japanese Media Making a view on the Fourth Plenary Session: China Will Control the Local Government from the Local Debt", http://finance.sina.com.cn/china/20141024/220020636832.shtml.

${ }^{2}$ In the Modern Chinese Dictionary, institution is regarded as an operation regulation or an action principle which require everyone to abide by. New institutional economics 
consider that institution is the regulation aggregation, is a series of the regulation network that are composed of formal constraint and informal constraint.

${ }^{3}$ The data mainly come from "the audit result of local government debt in Chia" (the 35th file in 2011) and "the audit result of governmental debt in China" (the 32nd file in 2013), which are both offered by the National Audit Administration of the PRC. Because the data are not published every year, the data in 1999, 2000, 2001, 2003, 2004, 2005, 2006, and 2011 of Fig. 1 were calculated in the average, on the basis of annual increase which was published by Auditing Administration.

${ }^{4}$ Referring to the research of Liu Rong and Huang Hong (2012), the central GDP and the local GDP are converted separately according to the proportionate relation between the local financial income and the central financial income. Otherwise, the evaluation of debt risk of local government should adopt the local GDP.

${ }^{5}$ The new debt of local government in 2012 is calculated by the average debt increment of this year which is relative to the year 2010.

${ }^{6}$ Xizang has not published the debt itself, so this research has no idea to take consideration about this province. Moreover, Guizhou and Tianjin have not announced the debt balance of the end of 2012 so that we only adapt the backward step-by-step method according to the balance of June in 2013 and the average debt growth of local government in the whole country.

${ }^{7}$ Except for Xizang, the local GDP in various regions is being calculated by the national GDP and the share of its own financial income to the total national financial income.

${ }^{8}$ The new debt of local government mainly considers the growth of half a year from the end of 2012 to June of 2013, relatively, the GDP also only regard the accumulated value of the second quarter in 2013.

${ }^{9}$ The data come from the China News Service website, "the investment and financing channel being suspected, a large number infrastructure being blamed for the government's achievement," (27 August 2012), http://finance.chinanews.com/cj/2012/08-27/ 4134493.shtml.

${ }^{10} \mathrm{Yu}$ Xiao (2005) suggests that there is the individual rationality as well as the social rationality in the human brain. The role of the individual rationality is produced naturally and does not need the education and the regulation of the institution. Besides, the social rationality plays a role of advocacy and education, that is to say, it need to be realized by the external compelling force and the public opinion. Reference on the website of law information in Peking University, http://article.chinalawinfo.com/article_print.asp?articleid $=35389$.

${ }^{11}$ The data come from the China News Service website, "Ministry of Finance has been approved to issue municipal bonds as agent for 233 billion yuan in 2012" (30 July 2012), http://finance.sina.com.cn/roll/20120730/200212709866.shtml.

${ }^{12}$ The data come from "the notice on the improvement to examine the political achievement for the local party and government leading bodies and other leading cadres" being issued by the Organization Department of the Central Committee of the CPC, (the legal library, 6 December 2013), http://www.law-lib.com/law/law_ view.asp?id $=438166$. 


\section{Author's information}

MXL works in the center for study of public policy in Yunnan University of Finance and Economics. He is a Ph.D., associate professor, and master's tutor. In recent years, the author published more than 20 articles in top journals such as Economic Research and Management World, presided over seven projects supported by the National Natural Science Foundation of China, the Humanity and Social Science Research of Education Ministry of China and other funding, participated in more than 30 projects supported by the National Natural Science Foundation of China, Ministry of Finance, the Yunnan provincial finance department, and so on. In addition, the author obtained the award of scientific research achievements of Higher Education Department, the award of scientific achievements of Philosophy and Social Sciences in Yunnan province and other awards, a total of 12 provincial awards.

\section{Authors' contributions}

$M X L$ is independently responsible for the entire contents of this article, including the design of article framework, data collection and analysis, and text writing, and agrees to be accountable for all aspects of the work in ensuring that questions related to the accuracy or integrity of any part of the work are appropriately investigated and resolved.

\section{Acknowledgments}

This article is funded by the Key Projects of Philosophy and Social Sciences Research in Ministry of Education: "Monitoring and Warning Mechanism Research of Public Finance Safety" (12JZD031), the National Natural Science Foundation of China: "Excavating Motivation and Modifying System Research of Local Government Debt Risk: based on the Responsibility Transfer Expected Model under the Space-time Separation of Power and Responsibility" (71303207), the Surface Project in Applied Basic Research of Yunnan Provincial Science and Technology Plan: "The Formation and Control of Local Government Debt Risk under the Space-time Separation of Power and Responsibility: Case in Yunnan Province" (2012FB168).

Received: 30 November 2015 Accepted: 26 February 2016

Published online: 21 April 2016

\section{References}

Fu R, Miao X, Wang M, Yang Y (2013) Construction of the mechanism of China's public financial security monitoring and early-warning: A theoretical research framework. Finance Trade Econ 8:18-26

Guo R (2009) The parity of authority and responsibility: Dissimilation and remediation. J Shenyang Normal University (Social Science Edition) 2:28-31

Huang G, Xu Y (2011) Analysis on the transmission mechanism and formation mechanism of local government debt risk. Public Finance Res 9:2-5

Islam MF, Hasan MS (2007) The macroeconomic effects of government debt on capital formation in the United States: An empirical investigation. Manchester School 75(5):598-616

Levine H (2011) The impact of debt management policies on borrowing costs incurred by U.S. state governments. Public Finance Manag 11(1):1-27

Liu R, Huang H (2012) Measurement, Evaluation and Release of China's local government debt risk. Economic Theory and Business Management 1: 82-88

Liu Y (2013) Debt soft constraint to weaken monetary control [EB/OL]. http://www.chinabond.com.cn/Info/15715573.

Lu C, Research group of Jingan County branch of people's Bank of China (2011) Investigation and analysis of local government debt and the relationship between the local economic development - Taking Jingan of Jiangxi as an example. J Finance Econ 12:84-86

Ma B, Guo R (2010) Equality or inequality of rights and responsibilities: Theory vs reality. Cass J Political Sci 1:72-78

Miao X, Fu R (2015) Division of powers and responsibilities, background of political performance and extraordinary growth of local government debt. Finance Trade Econo 4:17-31

Mikesell $J L$ (2002) The threat to state sales taxes from E-commerce: A review of the principal issues. Municipal Finance $J$ 23(3):48-61

Ming S, Zhihua F, Buming L, Juming K, Xitian L, Zhengwu H, Jian L, Haiman Y, Jinghua Z, Ainan H, Wenchao S, Songwei M, Fengqin H, Xuefeng S, Lean Y, Delong Q, Qiang W, Xiangman M (2011) Research on the local government debt issues in the developed coastal areas under the new situation - a case study of part of counties (cities) in Wenzhou and Suzhou. Rev Economic Res 10:18-28

Qi Z (1988) Philosophy of Management. The Press of Chinese Academy of Social Science.

Qi D (2001) On power. Chinese J Law 1:18-32

Qi M, Li Y (2006) Public administrative value, public interest and public responsibility - a three dimensional structure of scientific operation of public power. Acad China 6:28-35

Wang F (2000) On the principle of responsibility in accord with authority. J Guangdong Institute of Public Administration 4:16-17

Wei X, Chen H (2005) The Government Responsibility and the Local Management. The Press of Party School of the Central Committee of C.P.C.

Xie S, Bai Y (2013) Analysis on local government financing platform-credit accelerator effect under the dual impulse. Econ Theory Bus Manag 1:60-68

Yang S, Li S (2013) The determine of local government debt: an institutional framework. Reform of Economic Syst 2:15-19 Yang C, Lu Y (2013) Current situation, causes and countermeasures of local government debt risk. Public Finance Res 11:58-60 Yu C (2011) Current situation, causes and countermeasures of local government debt. Public Finance Res 9:5-7

Yu Xiao (2005) On the website of law information in Peking University. http://article.chinalawinfo.com/article_print. asp?articleid $=35389$. 